\title{
Waldemar Hoff
}

\section{Kosmopolityczna emancypacja sędziów}

\section{STRESZCZENIE}

Celem tego artykułu jest ustalenie cech charakterystycznych kosmopolityzmu sędziowskiego oraz jego skutku - uwolnienia sędziów z uwarunkowań prawa krajowego. Kosmopolityzm prawniczy cechuje tworzenie systemów normatywnych poza tradycyjnie pojętym prawem międzynarodowym. Podczas gdy to ostatnie istnieje z woli państw, normy kosmopolityczne są zwykle tworzone przez podmioty prywatne. Ich moc wiążąca jest konsekwencją praktycznej konieczności, a nie woli państw. Przykładami są lex sportiva, standardy narzucane przez agencje ratingowe oraz wymagania międzynarodowych ciał akredytacyjnych instytucji akademickich. Przez odwoływanie się do zewnętrznych źródeł prawa sędziowie uwalniają się od dotychczasowych ograniczeń, rozciągając swoją władzę na sferę tworzenia prawa.

Oceniając wpływ kosmopolityzmu na prawo, trzeba odróżniać posługiwanie się obcym prawem jako inspiracją intelektualną od traktowania go jako wiążącego źródła prawa. Szukanie inspiracji intelektualnej w obcych prawach i wyrokach wydaje się mało kontrowersyjne, jednak w rzeczywistości może tworzyć zagrożenia dla jakości orzecznictwa. Wśród tych zagrożeń można wymienić selektywne wybieranie obcych wzorów oraz przywoływanie ich bez solidnej wiedzy o ich kontekście społeczno-ekonomicznym w kraju pochodzenia. Występuje też niebezpieczeństwo nadużycia władzy przez wkraczanie sędziów w sferę zastrzeżoną dla władzy ustawodawczej. Pozytywnym skutkiem sięgania po obce koncepcje prawne jest możliwość wstępnej weryfikacji podejmowanych decyzji sprawdzonych na obcym gruncie.

Słowa kluczowe: kosmopolita, sędziowie, prawo 


\section{Waldemar Hoff}

\section{The Cosmopolitan Emancipation of Judges}

\section{ABSTRACT}

This article seeks to identify the characteristic features of judicial cosmopolitanism and its product - the emancipation of judges from the constraints of national law. Cosmopolitanism manifests itself in creating normative systems outside and above traditional international law. While the latter draws its binding power from the will of states, cosmopolitan rules are usually created by private actors. Their binding power results predominantly from practical necessity. Such is the status of lex sportiva, of the standards imposed by rating agencies, or of international accreditation bodies. Judicial cosmopolitanism is different, for it rests upon the existing structures and competencies. By resorting to alien legal sources judges free themselves from national constraints, thus enhancing their power and independence.

In assessing the impact of cosmopolitanism, one has to differentiate between looking up to foreign laws and precedents as binding sources, and treating them as merely intellectual inspiration. The second, albeit it seems innocuous, entails serious perils to the quality of adjudication. It creates a danger of cherry-picking by selecting foreign inspirations, not necessarily best suited to the case at hand. There is a danger of judicial overstepping of powers by making laws instead of merely applying it. By allowing judges to venture the uncontrolled expansion of their powers we endanger the very essence of the rule of law. On a positive note, drawing on foreign legal sources enables judges to verify the rationality of their decisions, as they were already tested in other jurisdictions.

Keywords: cosmopolitan, judges, law 


\section{CZYM JEST KOSMOPOLITYZM PRAWNY?}

W okresie kilku ostatnich dziesięcioleci rola sędziów uległa bardzo szybkiej transformacji. Jej skutkiem jest znaczący wzrost wpływu sędziów na życie społeczne i gospodarcze, przede wszystkim przez rozrost regulacji oraz przez wkraczanie sądów w sferę zastrzeżoną dla władzy prawodawczej i wykonawczej. Przyczyny tego zjawiska są liczne. Trzeba wśród nich wymienić zmiany strukturalne w tworzeniu i stosowaniu prawa, a w tym kosmopolityzację prawa. Ta ostatnia, jej istota, przyczyny i konsekwencje zostanie poddana analizie w tym artykule. Autor reprezentuje stanowisko, że występowanie prawotwórstwa kosmopolitycznego jest zjawiskiem bardzo rozpowszechnionym, jednak posługiwanie się przez sędziów normami kosmopolitycznymi jako podstawą orzekania występuje w bardzo wąskim zakresie. Na szerszą skalę sędziowie uwzględniają obce prawo jedynie jako źródło inspiracji intelektualnej. Jednak nawet w postaci niewiążącej praktyka ta może mieć istotne konsekwencje dla zasady praworządności, dlatego sięganie po obce koncepcje prawne powinno cechować się ostrożnością i dochowaniem rygorów metodologicznych.

Czym jest kosmopolityzm w prawie ${ }^{1}$ ? Kosmopolityzm prawny wyraża się $\mathrm{w}$ tworzeniu prawa nie $\mathrm{z}$ woli państw, lecz poza nimi, np. przez organizacje międzynarodowe o statusie prywatnym. Można wśród nich wymienić takie podmioty jak Międzynarodowy Komitet Olimpijski, przedsiębiorstwa działające w skali globalnej, agencje ratingowe określające kryteria oceny krajowych systemów gospodarczych, globalne systemy akredytacyjne dla wyższych uczelni oraz organizacje ustanawiające standardy rachunkowości oraz inne podmioty o zasięgu globalnym, wystarczająco silne, aby wymusić posłuszeństwo dla stanowionych przez siebie reguł².

Uniwersalnego zasięgu norm kosmopolitycznych nie należy brać dosłownie. Jest to raczej stan gotowości danego systemu do objęcia swym zasięgiem społeczności globalnej niż wpływ rzeczywisty. Np. każda uczelnia wyższa może podporządkować się regułom panującym w danym między-

1 Krótki przegląd poglądów o pojęciu kosmopolityzmu przedstawia M. Soniewicka, Granice sprawiedliwości, sprawiedliwość ponad granicami, Warszawa 2010, s. 262-279.

2 Sankcja nie ma charakteru przymusu, jakimi rozporządzają suwerenne państwa. Wiąże się ona zwykle z dostępem do „dóbr" pożądanych przez adresatów, np. reputacji wynikającej z miejsca w rankingu. 
narodowym systemie akredytacji, lecz tylko pewna ich część uzna to za potrzebne. Podobnie sędziowie uzgadniający poglądy w globalnej sieci sędziowskiej ani nie reprezentują całej globalnej społeczności sędziowskiej, ani też nie wywierają na nią pełnego wpływu.

Normy, które można uznać za kosmopolityczne, nie mieszczą się granicach pojęcia prawa międzynarodowego, ponieważ ich tworzenie i obowiązywanie nie zależy od państw ${ }^{3}$. Niektóre $\mathrm{z}$ nich, takie jak lex sportiva, tworzone są właśnie w tym celu, aby uniknąć władztwa państwowego ${ }^{4}$. Niekiedy, jak w przypadku prawa sportowego, za systemami normatywnymi stoją prywatne organizacje quasi-państwowe z ciałami legislacyjnymi, władzą wykonawczą i sądowniczą. Niekiedy kosmopolityzacja jej ubocznym skutkiem działania państw. Np. państwa tworzą i finansują sieci organów regulacyjnych lub sieci sądowe takie jak Europejska Sieć Sądowa w Sprawach Cywilnych i Handlowych ${ }^{5}$, po czym członkowie sieci dokonują uzgodnień nieprzewidzianych przez państwa założycielskie.

Źródłem kosmopolityzmu prawnego jest także aktywność sądów i indywidualnych sędziów poszukujących uzasadnienia wyroków poza własnym, krajowym systemem prawnym. Aktywność ta jest ściśle powiązana z kosmopolityzmem doktrynalnym (prawniczym), czyli aktywnością środowisk akademickich, bardzo podzielonych w kwestii dopuszczalności i skutków sięgania po obce koncepcje prawne. Zgodnie z terminologią często używaną $\mathrm{w}$ piśmiennictwie poświęconym kosmopolityzmowi prawo międzynarodowe mieści się $\mathrm{w}$ granicach ładu zaprowadzonego po pokoju westfalskim z 1648 r., gdyż normy prawa międzynarodowego wiążą je tylko z woli państwa. Nie jest przejawem kosmopolityzmu prawniczego, $\mathrm{w}$ wyżej zarysowanym znaczeniu, stosowanie prawa europejskiego oraz międzynarodowego $w$ granicach, w jakich wynika ono z woli państw. Przykładem takiego powiązania z prawem obcym jest irlandzka ustawa o Konwencji Praw Człowieka z 2003 r., wymagająca w art. 2 uwzględnienia przepisów Konwencji w interpretacji prawa w największym możliwym

\footnotetext{
3 Niektórzy, moim zdaniem błędnie, upatrują elementów kosmopolitycznych w wyrokach trybunałów arbitrażowych wolnych od wpływów politycznych. A. Bogdandy, I. Ventzke, Beyond Dispute: International Judicial Institutions as Lawmakers, German Law Journal, Nr 12/2011, s. 994.

4 Szerzej M. James, Sports Law, New York 2010, s. 7-8, 55-57 i 303-304.

5 European Judicial Network In Civil and Commercial matters ustanowiona decyzją Rady z 28 maja 2001 r. 2001/470/EC, 0.J. L 174, 27.6.2001, s. 25.
} 
stopniu ${ }^{6}$. Wymiar kosmopolityczny będą jednak miały normy wywiedzione przez sędziów, jeśli granice upoważnienia przez państwa zostały przekroczone lub nie można ich ustalić.

Tymczasem normy kosmopolityczne obywają się bez akceptacji państwa. Wiążą dlatego, że zawierają odmienny od państwowego rodzaj przymusu, np. podporządkowanie się standardom rachunkowości lub wymogom akredytacyjnym leży interesie adresatów tych norm; podporządkowanie się wymogom Międzynarodowego Komitetu Olimpijskiego jest konieczne, jeśli dane państwo chce gościć igrzyska sportowe. Wyjątkiem jest władztwo sędziowskie, gdyż sędziowie wykorzystują istniejące sankcje państwowe, działające także wtedy, gdy sędzia „przemyca” w wyroku obce koncepcje prawne.

Jedną z konsekwencji powoływania się na obce prawo jest swoista emancypacja sędziów, którzy uwalniają się od krępujących ich ograniczeń w tym ograniczenia do stosowania prawa, do stosowania prawa własnej jurysdykcji, a nawet prawa w ogóle. Problem ten nakłada się na tendencję do rozszerzania władzy dyskrecjonalnej sędziów także w praktyce krajowej i europejskiej, co zdaniem części piśmiennictwa samo w sobie stanowi tworzenie prawa ${ }^{7}$. Jest to zjawisko nieprzewidziane przez konstytucje współczesnych państw, które niezwykle rzadko zajmują zdecydowane stanowisko w kwestii posługiwania się obcymi koncepcjami prawnymi. Do wyjątków należy Konstytucja RPA sprzyjająca korzystaniu z bliżej niesprecyzowanych przepisów prawa międzynarodowego i obcego. Prawie nieznane współczesnemu prawu jest zakazywanie korzystania z obcych systemów prawa ${ }^{8}$. Jak wiadomo, zmiany wprowadzone w Konstytucji stanu Oklahoma nie doszły do skutku na skutek uznania poprawki za niezgodą z konstytucją Stanów Zjednoczonych ${ }^{9}$. Praktyczne kroki przeciwników czerpania z obcych wzorów również są rzadkie w sferze tzw. zachodniej kultury prawa. Do wyjątków należy zaliczyć nieudaną próbę zastosowania procedury

\footnotetext{
6 European Convention on Human Rights Act 2003.
}

7 R. Brandom, Some pragmatist themes in Hegel's Idealism: Negotiation and Administration of Hegel's Account of the Structure and Content of Conceptual Norms, European Journal of Philosophy, Vol. 7, Issue 2/1999, s. 181.

8 We Francji nie należy ujawniać obcych źródeł w wyrokach sądowych, zob. B. Markesinis, J. Fedtke, The Judge as Comparatist, Tulane Law Review, No. 80/2005-2006, s. 30.

9 A.Ch. Bryant, Foreign Law as Legislative Fact in Constitutional Cases, BYU Law Review, No. 4/2011, s. 1006. Tekst dostępny: http://digitalcommons.law.byu.edu/lawreview/vol2011/iss4/1. 
impeachmentu wobec sędziego A. Kennedy'ego za przywołanie obcego prawa w sprawach Lawrence i Roper ${ }^{10}$.

Klarowność podziału na normy prawa międzynarodowego i normy kosmopolityczne, w tym wywiedzione lub zapożyczone przez sędziów, zakłóca zwyczajowe prawo międzynarodowe ${ }^{11}$, powstające bez udziału państw oraz konstytucja Republiki Południowej Afryki w art. 39. Przepis tego artykułu nakazuje uwzględnienie (consideration) prawa międzynarodowego w podejmowaniu decyzji oraz dopuszcza uwzględnianie prawa innych państw. Zatem w świetle przyjętej tu definicji przywołanie prawa obcego przez sędziego z RPA nie mieściłoby się $\mathrm{w}$ koncepcji kosmopolityzmu prawnego, ponieważ takie odwołanie dokonuje się z woli państwa. Pokazuje to umowność powyższej klasyfikacji, ale też tendencyjne prezentowanie problemu w piśmiennictwie. Mimo że jest to konstrukcja szeroko komentowana przez zwolenników kosmopolityzmu prawnego, trudno w piśmiennictwie znaleźć szczegółowe wyjaśnienie konstytucyjnego terminu „uwzględniać”. Czy w art. 39 chodzi o uznanie obcego prawa za formalną podstawę decyzji, czy tylko czerpanie z intelektualnych zasobów zawartych w obcym prawie, pozostaje nierozstrzygnięte.

Problem obowiązywania norm kosmopolitycznych występuje także w świetle Konstytucji RP dopuszczającej bezpośrednie stosowanie na terytorium państwa ratyfikowanych umów międzynarodowych oraz prawa ponadpaństwowego, tj. przepisów ustanowionych przez organizacje lub organy międzynarodowe upoważnione do tego w trybie określonym w art. 90. Konstytucja milczy w kwestii związania normami tego typu i ich stosowaniem. W pewnym sensie jest to milczenie pozorne, gdyż kosmopolityczne systemy prawne, z wyjątkiem kosmopolityzmu sędziowskiego, mieszczą się w granicach koncepcji prawa prywatnego. Mogą być zatem przestrzegane przez zainteresowane strony bez udziału państwa, który nie jest potrzebny, gdyż systemy te mają swoje własne sankcje i sposoby rozstrzygania sporów, np. sądy sportowe. Ponadto formalne obowiązywanie jakiegokolwiek obcego prawa na terytorium RP jest możliwe tylko po spełnieniu określonych w Konstytucji warunków ratyfikacji i powierzenia. W przypadku aktywności sędziowskiej sytuacja jest odmienna ze względu na

\footnotetext{
10 Ibidem, s. 1030.

${ }^{11}$ C.G. Buys, Burying Our Constitution in the Sand? Evaluating the Ostrich Response to the Use of International and Foreign Law in U.S. Constitutional Interpretation, Brigham Young University Journal of Public Law, Vol. 21/2007, s. 5.
} 
publicznoprawny status sędziów i wykorzystywanie przez nich autorytetu państwa bez wyraźnego upoważnienia wtedy, gdy zapożyczają w sposób nieformalny niepolskie i nieunijne konstrukcje prawne. Pogląd ten jest jednak dyskusyjny, o czym świadczą wypowiedzi dowodzące, że nawet w tak izolacjonistycznych kulturach prawnych jak amerykańska korzystanie z obcych źródeł zawsze było konstytucyjnie dopuszczalne i praktykowane ${ }^{12}$. Problem zaciemnia to, że zazwyczaj sędziowie nie powołują się na obce prawo i precedensy jako formalnoprawną podstawę orzekania, lecz raczej jako materiał pomocniczy pozwalający wyrobić sobie opinię o skutkach społecznych rozmaitych wariantów decyzji. Większość teoretyków nie czyni rozróżnienia pomiędzy takim formami zapożyczeń jak uwzględnianie skutków określonych rozwiązań prawnych, co można uznać wręcz za pożądane, a nadawaniem treści krajowym przepisom, zwłaszcza konstytucyjnym, z uwzględnieniem obcych wzorów, co stanowi zagrożenia dla zasady praworządności ${ }^{13}$.

\section{2 \\ OBCE PRAWO - INSPIR ACJA INTELEKTUALNA, CZY PODSTAWA PRAWNA?}

Podstawowym problemem w stosowaniu przez sędziów obcego prawa jest to, czy przywoływane przepisy, precedensy lub koncepcje są traktowane jako formalna podstawa wyrokowania? W większości przypadków tak nie jest. Niekiedy zbieżność treści wyroków nie jest przypadkowa, jak w sprawach D.P.P v. Boyce (Irlandia) i Schmerber v. California (USA) oraz Saunders przeciwko Zjednoczonemu Królestwu (Europejski Trybunał Praw Człowieka) ${ }^{14}$, ale nie występuje element formalnego powiązania między elementami (przepisami, precedensami) rozmaitych systemów. W wyrokach SN USA, przywoływanych jako przykład kosmopolityzmu, powiązania $\mathrm{z}$ zagranicznym doświadczeniami wyrażają się przede wszystkim $\mathrm{w}$ zastosowaniu metody komparatystycznej. Np. w sprawie Lawrence v. Texas

\footnotetext{
12 Ibidem, s. 2.

${ }^{13}$ Do wyjątków należy Z. Larsen, Discounting Foreign Imports: Foreign Authority in Constitutional Interpretation \& the Curb of Popular Sovereignty, Willamette Law Review, No. 45/2009, s. 1291.

14 J.L. Murray, Judicial Cosmopolitanism, Judicial Studies Institute Journal, No. 2/2008, s. 12-13.
} 
sąd ${ }^{15}$, decydując o dopuszczalności sodomii homoseksualnej, powołał się na prawo innych państw, przy czym ograniczył się do zachodniej kultury prawnej, co zaprzecza uniwersalizmowi przyjętych podstaw aksjologicznych w nie mniejszym stopniu niż dopatrywanie się neokolonializmu w krzewieniu zachodniej koncepcji praworządności ${ }^{16}$.

Wymaga też podkreślenia, że w całej serii wyroków ten sam Sąd Najwyższy Stanów Zjednoczonych nie badał uzasadnień obcych decyzji, lecz jedynie odwołał się do akademickich danych komparatystycznych ${ }^{17}$. Co więcej, znaczna część stanowisk skłaniających się do korzystania z obcych wzorów to zdania odrębne i wypowiedzi wygłaszane przez sędziów prywatnie poza sądem ${ }^{18}$. Nawet zamieszczenie uwag odnoszących się do obcych wzorów w uzasadnieniach wyroków, jak to uczynił sędzia A. Kennedy w wyroku Lawrence $v$. $\operatorname{Texas}^{19}$, nie przesądza jeszcze o tym, że ów wzorzec był traktowany przez piszących jako wiążący. Z formalnoprawnego punktu widzenia czerpanie inspiracji intelektualnej ze źródeł zewnętrznych w stosunku do danego systemu prawnego może wydawać się nieistotne. Sędziowie i tak są pod wpływem ideologii typowych dla czasów, w których orzekają. A jednak ten nieformalny wpływ jest ważny z dwóch powodów. Pierwszy jest taki, że miękki wpływ obcego prawa, choć ani nakazany, ani zakazany, może mieć przemożny wpływ na krajowy system prawny, czego przykładem jest uniwersalne nieomal stosowanie testu SSNIP w orzecznictwie antymonopolowym ${ }^{20}$. Nie bez racji sędzia SN USA A. Scalia stwierdził, że przywoływanie obcych źródeł może podważać zarówno interpretację

\footnotetext{
15 Z. Larsen, op. cit., s. 1283-1284.

${ }^{16}$ Zarzut obejmuje nie tylko wybiorczość w czerpaniu obcych wzorów, lecz także ignorowanie tego, że w tzw. liberalnych demokracjach również dochodzi do naruszeń praw człowieka, tak: B.F. Fitzgerald, An emerging Liberal Theory of International Law and the Non-Enforcement of Foreign Public Laws, Australian Yearbook of International Law, No. 16/1995, s. 314.

17 Ibidem, s. 1286.

${ }^{18} \mathrm{~Np}$. wypowiedzi sędzi D. 0'Connor oraz B. R. Ginsburg, zob. J.J. Murray, op. cit., s. 4-5. Także D. Kennedy, My Talk at the ASIL: What is New Thinking in International Law, Proceedings of the Annual Meeting (American Society of International Law), Vol. 92/April 5-8 2000, passim; R.A. Posner, What Am I? a Potted Plant?, The New Republic, September 28, 1987, s. 23-25. Argumenty w obronie aktywizmu sędziowskiego wskazuje np. M. Kirby, Judicial Activism: Authority, Principle and Policy in the Judicial Method, London 2004, passim.

19 J.L. Murray, op. cit., s. 6.

${ }^{20}$ Small but Significant Nontransitory Increase of Price - Jest to metoda prowadząca do ustalenia substytutywności towarów w prawie antymonopolowym, pomocna w ustaleniu pozycji dominującej na rynku właściwym.
} 
konstytucji opartą na tych źródłach, jak i autorytet całego sądu ${ }^{21}$. Problem polega przede wszystkim na trudności odróżnienia w praktyce, czy mamy do czynienia tylko z inspiracją lub posługiwaniem się obcym źródłem jako faktem, czy też sędzia uważa obcą normę materialnoprawną za podstawę wyroku. Jeśli prawo jest instrumentem rozwiązania określonego problemu społecznego lub ekonomicznego, to wiedza o obcych przepisach, praktykach i konsekwencjach pewnych rozwiązań niewątpliwie wzbogaca sąd orzekający, niezależnie od tego na ile systematyczne i naukowe były metody jego badania.

Drugi powód to narastająca konwergencja prawa i filozofii tam, gdzie przedmiotem orzekania są pojęcia ogólne, takie jak proporcjonalność, ochrona życia, tortura, okrutna kara (cruel and unusual punishment). Wyjaśnienie tych pojęć z natury rzeczy wymaga odwołania się do dorobku całej ludzkości lub przynajmniej do kultury prawnej społeczeństw mających wspólne korzenie kulturowe.

Swoboda sędziów w korzystaniu z koncepcji filozoficznych i prawnych nie jest nieograniczona, gdyż, paradoksalnie, obce koncepcje muszą być zasadniczo zgodne z kulturą prawną państwa je przyjmującego. Możliwa wadliwość zapożyczenia jest trudno rozpoznawalna ze względu na ustrojową pozycję sądu. Budzące kontrowersje wyroki są bowiem wydawane przez sądy konstytucyjne i sądy najwyższe, których decyzje nie podlegają weryfikacji przez inne podmioty. Poza krytyką ze strony piśmiennictwa naukowego i prasy nie istnieją żadne środki presji hamujące recepcję obcych koncepcji prawnych.

\section{GLOBALNE SIECI SĘDZIOWSKIE JAKO INSTRUMENT EMANCYPACJI SĘDZIÓW}

Choć może wydać się nieprawdopodobne, aby prawnik świadomie zmierzał do zerwania z prawem, część piśmiennictwa (w recenzowanych czasopismach naukowych) wyraźnie opowiada się za przyzwoleniem na tworzenie

\footnotetext{
21 Ten pogląd sędzia A. Scalia wypowiedział w odniesieniu do interpretacji konstytucji Stanów Zjednoczonych. Jak sam stwierdził, sięganie po obce prawo jest dopuszczalne w RPA, ponieważ konstytucji RPA wprost tak stanowi. J.L. Murray, op. cit., s. 6.
} 
prawa przez sędziów oraz odrzuceniem zasad praworządności przynajmniej w jej anglosaskiej wersji znanej jako the rule of law ${ }^{22}$. M.A. Jayatilake jest zwolenniczką wykorzystania międzynarodowych sieci sędziowskich jako właściwego miejsca do tworzenia prawa zamiast podporządkowania sędziów zasadzie praworządności i regułom demokracji większościowej ${ }^{23}$. Szczególną rolę w tej wizji odgrywają sądy konstytucyjne, które, paradoksalnie, w kosmopolitycznej wizji prawa powinny być niezależne od krajowych i konstytucyjnych ograniczeń ('independent of national and constitutional controls $)^{24}$. Podobnie wypowiadają się filozofowie, wśród nich S. Žižek ${ }^{25}$.

Kosmopolici są przeciwni narzucaniu sędziom programów, m.in. Banku Światowego i Międzynarodowego Funduszu Walutowego, skierowanych na podnoszenie poziomu praworządności i sprawności sądownictwa, ponieważ zwierają treści właściwe zachodniej kulturze prawnej, a przez to stają się swoistą formą neokolonializmu ${ }^{26}$. Wprawdzie w piśmiennictwie chodzi o kraje rozwijające się, to jednak zarzut neokolonializmu lub globalnej hegemonii może odnosić się do jakiegokolwiek systemu prawnego w kraju postrzegającym się jako niezachodni lub gospodarczo mniej rozwinięty. W piśmiennictwie udokumentowano np. „eksport” prawa amerykańskiego do Europy Wschodniej ${ }^{27}$.

Pominąwszy zasadność tych oskarżeń2 ${ }^{28}$, trudno oprzeć się wrażeniu, że walka z neokolonializmem jest tylko listkiem figowym dla rzeczywistego celu kosmopolitów, jakim jest legitymizacja przejęcia przez sędziów kompe-

\footnotetext{
22 Pomijam różnice pomiędzy koncepcją rule of law i europejskim-kontynentalnym rozumieniem zasady praworządności, tym bardziej, że uważam je za mniej istotne niż to się przyjmuje w doktrynie.

${ }^{23}$ M.A. Jayatilake, The Global Judicial Network: Towards New Hope for Development, Democracy and Equality in the Global Era, Sri Lanka Journal of International Law, No. 21(2)/2009, s. 167. Podobnie, lecz z naciskiem na przejęcie przez sędziów funkcji prawodawczych A. von Bogdandy, I. Vetzke, Beyond dispute: International Judicial Institutions as Lawmakers, German Law Journal, No. 12/2011, s. 982-983.

${ }^{24}$ M.A. Jayatilake, op. cit., s. $142-143$.

${ }^{25}$ Autor ten buduje międzynarodowy i ponadpaństwowy ład organizacyjny na wartościach takich jak ochrona przed zmianami klimatu. Konsekwencją takiego podejścia ma być np. „globalne obywatelstwo klimatyczne". S. Žižek, op. cit., s. 89-90.

${ }^{26}$ M.A. Jayatilake, op. cit., s. 156-164.

${ }^{27}$ Eksport prawa dokonywał się za pośrednictwem CEELI (Central and East European Law Initiative), szerzej, Y. Dezalay, B.G. Garth (ed.), Lawers and the Rule of Law in an Era of Globalization, Abingdon 2011, s. 137-151.

${ }^{28}$ Osobnym zagadnieniem jest to, czy Zachód, w tym Europa, zasadnie uważa się za moralny wzorzec dla reszty świata. Krytyczne stanowisko w tej sprawie zajmują U. Beck i E. Grande, Europa kosmopolityczna. Społeczeństwo i polityka w drugiej nowoczesności, Warszawa 2009, s. 306-312.
} 
tencji prawotwórczych. Szermując argumentem neokolonializmu prawniczego, kosmopolici popadają w sprzeczność, ponieważ a priori odrzucają istnienie nadrzędnych, uniwersalnych zasad prawa, przynajmniej w przewidywalnej przyszłości. Jeśli bowiem można odrzucić doktrynę rule of law, nie ma powodu, aby uznawać jakąkolwiek doktrynę prawną lub filozoficzna, np. Immanuela Kanta ${ }^{29}$ lub Konfucjusza ${ }^{30}$. Selektywne decydowanie ${ }^{31}$, oczywiście przez sędziów, o tym, co jest prawem - pod kątem potrzeb społeczności lokalnych - unicestwia uniwersalizm, chyba że sędziom udałoby się zbudować własny system aksjologiczny i normatywny.

Przykładów wybiórczości nie brakuje w orzecznictwie, np. w sprawie United States v. Cotrioni z roku 1989. Jak pisze K.G. Young, wyrok był przykładem rozminięcia się prawa międzynarodowego z prawami człowieka ${ }^{32}$. Inaczej niż to zwykle bywa, uznano, że dopuszczalne są prawnomiędzynarodowe ograniczenia prawa pobytu cudzoziemca w Kanadzie w oparciu o prawo międzynarodowe, wbrew przepisom kanadyjskiej Karty Praw i Podstawowych Wolności. Krytycy wyroku najwidoczniej uznali, że ogólnie sformułowane prawa fundamentalne reprezentują porządek prawny wyższego rzędu nad prawem międzynarodowym, mimo że, formalnie biorąc, były one częścią prawa kanadyjskiego.

Kosmopolici wypowiadają się zdecydowanie za rozszerzeniem władzy sędziowskiej poza stosowanie i interpretowanie prawa. Sędziowie, ich zdaniem, stali się podmiotami globalnego ładu (actors of global governance). Odrzucenie tradycyjnej roli sędziów musi skutkować odrzuceniem dotychczasowej koncepcji prawa międzynarodowego. Istnieje ogromna literatura podważająca postwestfalską koncepcję prawa przyznającą szczególną a nawet wyłączoną rolę w jego tworzeniu suwerennym państwom. Kosmopolityzm wnosi nowy element w procesie podważania ładu westfalskiego przez przyznanie szczególnej roli sędziom, których decyzje, ugruntowane w regułach ponadnarodowych bardziej niż w konstytucjach krajowych, powinny nadawać kierunek polityce tworzenia prawa. Formalne i nieformalne

${ }^{29} 0$ wpływie I. Kanta na doktrynę kosmopolityzmu zob. R. Fine, Cosmpolitanism, London-New York 2007, s. 22-35.

${ }^{30}$ L. Zhaoije, Legacy of Modern Chinese History; its Relevance to the Chinese Perspective of the Contemporary International Legal Order, Singapore Journal of the International \& Comparative Law, No. 5/2001, s. 314-317.

31 W literaturze anglojęzycznej określane zwykle jako cherry-picking, np. K.G. Young, The World, through the Judge's Eye, Australian Yearbook of International Law, Vol. 28/2009, s. 33.

32 Ibidem, s. 45. 
sieci sędziowskie o zasięgu globalnym mają służyć uzgadnianiu stanowisk i formułowaniu zasad. Normy mają być tworzone w drodze sędziowskiego dialogu, co ma doprowadzić do ukształtowania się „władzy interaktywnej” (interactive authority). Nowe terminy takie jak transjudicialism oraz judicial comity są nie tyle konsekwencją kosmopolityzmu, co instrumentem ułatwiającym osiągnięcie celu. Skoro sędzia staje się podmiotem tworzącym prawo $^{33}$, tworzenie nowych terminów i nadawanie nowego znaczenia starym zaciera ślady burzenia dotychczasowego porządku i legitymizuje nowy. Burzenie zostaje powiązane z ideologią rewolucyjna, w której władza sędziowska podporządkowana jest celom politycznym, takim jak wyzwolenie spod kulturowej dominacji Zachodu oraz wyzwolenie społeczne zarówno od międzynarodowego kapitału jak i lokalnej biurokracji. Przykładowo, to sędziowie zdecydowali o dopuszczalność pozwów osób biednych z pominięciem ustalonych przez prawo wymogów, w tym przez osoby trzecie $\mathrm{w}$ ich imieniu ${ }^{34}$. Rozważane są też koalicje sieci sędziowskich z sieciami regulacyjnymi i finansowymi ${ }^{35}$.

\section{PRAWA CZŁOWIEKA JAKO SZCZEGÓLNE ŹRÓDŁO WŁADZY SĘDZIOWSKIEJ}

Prawa człowieka zajmują szczególne miejsce w kosmopolitycznej teorii prawa $^{36}$. Przede wszystkim stanowią uzasadnienie dla sięgania przez sędziów po prawo międzynarodowe i obce, jak również praktyki i opinie w celu interpretacji przepisów konstytucji krajowych. Są one jednocześnie punktem odniesienia, standardem traktowania i jednocześnie przedmiotem ochrony. Sędziowie sięgają poza normy własnego systemu prawnego w celu

\footnotetext{
${ }^{33}$ M.A. Jayatilake, op. cit., s. 146.

${ }^{34}$ Ibidem, s. 150-152.

350 integracji sieci zob. M. Castells, The Rise of the Network Society, Blackwell Publishing 2000, s. 501-509. Castells rozumie globalizację jako kolejną wersję „społeczeństwa sieciowego", które jest z natury globalne. Idem, The Network Society. From Knowledge to Policy, [w:] The Network Society. From Knowledge to Policy, eds. M. Castells, G. Cardozo, Centre for Transatlantic Relations, 2005, s. 4-5.

${ }^{36}$ N.p. M. Ignatieff, Human Rights as Idolatry, [w:] K.A. Appiah, D. Hollinger, Th.W. Laquer, D.F. Orentlicher, Human Rights as Politics and Idolatry, Princeton University Press 2001, Princeton, s. 8.
} 
ochrony praw podstawowych na własnym terytorium. Daje to szerokie pole do selektywności wyboru źródeł, koncepcji, faktów ${ }^{37}$ i wartości ${ }^{38}$, ponieważ na obecnym etapie rozwoju zarówno same prawa, jak i oparte na nich orzecznictwo tworzą mało spójną mozaikę. Nie ulega obecnie wątpliwości, że rozmaite prawa człowieka wzajemnie ze sobą konkurują ${ }^{39}$, dając w ten sposób okazję do ich „,ważenia”, co rozszerza zakres sędziowskiej władzy dyskrecjonalnej. Pojęcie władzy dyskrecjonalnej sędziów, mimo licznych odniesień w piśmiennictwie, pozostaje słabo zbadane, zwłaszcza w kontekście prawa administracyjnego. Przykład prawa administracyjnego szczególnie jasno wskazuje na to, że sędziowska swoboda w zakresie doboru podstaw aksjologicznych orzekania przyniosła zwrot stosunku sądów i doktryny do władzy dyskrecjonalnej.

Nie wymaga szerszego omówienia charakterystyczna dla prawa administracyjnego podejrzliwość wobec władzy uznaniowej. Historia rozwoju prawa i orzecznictwa administracyjnego jest tożsama $\mathrm{z}$ dążeniem do ograniczania władzy uznaniowej. W podobnym kierunki poszedł rozwój prawa europejskiego. Np. tzw. dyrektywa usługowa bardzo ograniczyła posługiwanie się uznaniem administracyjnym przez prawodawcę krajowego w zakresie reglamentacji transgranicznego oferowania i wykonywania usług $^{40}$. Tymczasem odwoływanie się do standardów ponadnarodowych zrywa z dotychczasową doktryna, choć formalnie jej nie zaprzecza. Stosowanie prawa administracyjnego, i nie tylko jego, jest w coraz większym stopniu uzależnione od kryteriów zawartych w szeroko rozumianych prawach podstawowych. Uznanie, zwalczane przez sądy i doktrynę w prawie krajowym, zostało rozszerzone do niespotykanych dotąd rozmiarów za sprawą ogólnych formuł, którymi posługują się prawa podstawowe. Wynika to $\mathrm{w}$ znacznym stopniu z potrzeby osiągnięcia kompromisu pomiędzy sygnatariuszami umowy międzynarodowej. W rezultacie nawet treść podstawowych pojęć jest sygnatariuszom nieznana w chwili podpisywania umowy. Zostanie ona ustalona w przyszłości przez sędziów po wystąpieniu

${ }^{37} 0$ władzy dyskrecjonalnej sędziów w zakresie doboru faktów zob. A. Schleifer, The Failure of Judges and the Rise of Regulators, London 2012, s. 23-52.

${ }^{38} \mathrm{~Np}$. pojęcie godności ludzkiej będzie rozumiane zupełnie inaczej w obrębie tej samej kultury prawnej przez chrześcijańskiego fundamentalistę i świeckiego obrońcę praw człowieka, tak C. Gearty, Principles of Human Rights Adjudication, 0xford-New York 2005, s. 85.

390 konkurencji praw podstawowych zob. C.G. Buys, op. cit., s. 53.

${ }^{40}$ Dyrektywa 2006/123/WE Parlamentu Europejskiego i Rady z dnia 12 grudnia 2006 r. dotycząca usług na rynku wewnętrznym (Dz. Urz. UE L 376 z 27.12.2006). 
sporu. W rezultacie wady przypisywane stosowaniu uznania administracyjnego w prawie krajowym zostają powiększone i przeniesione na płaszczyznę prawa międzynarodowego.

Tam gdzie sędziowie odwołują się do konkretnych aktów prawa międzynarodowego, a swoboda interpretacyjna mieści się w prawnie i doktrynalnie znanych granicach, praktyka ta nie ma waloru działań kosmopolitycznych, ponieważ, tak jak i normy umów międzynarodowych, jest pochodną woli państw. Jeśli sędziowie odwołują się do zasad i norm niewyrażonych w ratyfikowanych umowach międzynarodowych, np. do opinii społeczności międzynarodowej, konsensusu lub cywilizowanych praktyk, wówczas, na skutek braku powiązania $\mathrm{z}$ wolą suwerennych państw $\mathrm{w}$ tworzeniu owych norm, dochodzi do przeniesienia orzekania na płaszczyznę kosmopolityczną.

Powyższe rozróżnienie pozwala wyodrębnić taki stan rzeczy, w którym sędziowie są wyemancypowani (wyalienowani) z krajowego porządku prawnego na skutek z góry założonego planu świadomego, przez powierzenie im szerokich kompetencji do nadawania znaczenia pojęciom i normom (np. w dziedzinie międzynarodowego arbitrażu gospodarczego) oraz sytuację, gdy ich emancypacja wynika z aktywizmu sędziowskiego, np. w międzynarodowych sieciach sędziowskich. Dynamiczne rozumienie emancypacji sędziowskiej przejawia się $\mathrm{w}$ działaniach instytucji powołanych przez państwa, jeśli instytucje te, $\mathrm{w}$ tym przypadku sądy, podejmują działalność prawotwórczą poza zakresem aktów je konstytuujących. W praktyce niezmiernie trudno jest wskazać linię oddzielającą władztwo uznaniowe mieszczące się $\mathrm{w}$ granicach podyktowanych przez prawo i ustalone praktyki, a uzurpację władzy prawodawczej przez wymiar sprawiedliwości. Problem ten nie został do dziś rozstrzygnięty mimo bardzo burzliwej dyskusji amerykańskich środowisk naukowych odnoszącej się do wyroków nawiązujących do obcego prawa i praktyk, jak np. w związku ze sprawą Atkins v. Virginia ${ }^{41}$.

Ogólnikowość ram konstytucyjnych, w jakich orzekają sędziowie, tworzy szerokie pole do manipulacji pojęciami. Ilustracją takiego podejścia jest uznanie w sprawie Roper $v$. Simons ${ }^{42}$, że istnieje szeroki międzynarodowy konsensus w sprawie niedopuszczalności zastosowania kary śmierci

\footnotetext{
${ }^{41}$ Atkins v. Virginia, 536 U.S. 304, 316 (2002).

42 Roper v. Simmons 543 U.S. 551 (2005), szeroko komentowany, zob. np. W.P. Quigley, Revolutionary Lawyering: Addressing the Root Causes of Poverty and Wealth, Washington Journal of Law and Policy, Vol. 20/2006, s. 119.
} 
wobec niepełnoletnich. W wyroku wyrażono pogląd, że Stany Zjednoczone są jedynym państwem na świecie, które wciąż dopuszcza karę śmierci dla niepełnoletnich. Tymczasem zarówno w chwili orzekania, jak i obecnie prawo kilku państw przewiduje odmienne rozwiązania, czego przykładem są Chiny, Kongo, Pakistan, Nigeria, Iran i Arabia Saudyjska. Jeśli spojrzeć na to zjawisko przez pryzmat populacji, a nie ilości państw, to sama tylko obecność Chin i Pakistanu na powyższej liście czyni omawianą praktykę bardzo rozpowszechnioną. Zaś w krajach, w których ją oficjalnie zniesiono, pozostaje ona zgodna z moralnością społeczeństwa, czego dowodem były zamieszki w Indiach wywołane tym, że sąd skazał 17-letniego gwałciciela tylko na karę więzienia ${ }^{43}$. Podobnie Sąd Najwyższy USA błędnie przyjmował istnienie konsensusu w społeczeństwie amerykańskim wobec problemów, których dotyczyły wyroki ${ }^{44}$. Powyższe przykłady nie tylko ilustrują metodologiczne błędy w konstruowaniu założeń aksjologicznych wyroków, lecz także świadczą o tym, że uniwersalizm wartości i zasad uzasadniających kosmopolityczne podejście w procesie wyrokowania jest mniejszy, niż twierdzą kosmopolici.

Jedną z cech charakterystycznych tej debaty jest nieodróżnianie sięgania do prawa i orzecznictwa międzynarodowego, a prawa innych państw oraz użytku, jaki sędziowie robią z obcych wzorów. Częścią tego ostatniego problemu jest brak jasności, czy sędziowie istotnie traktowali obce wzory jako wiążące. Jeśli nie, co zdaje się wynikać nawet z chwiejnych opinii zwolenników kosmopolityzacji orzecznictwa ${ }^{45}$, to cały problem wydaje się mocno przesadzony. Byłby on problemem rzeczywistym, gdyby wbrew konstytucji i panującej doktrynie przywołano obcy precedens lub przepis jako formalną podstawę wyroku.

\footnotetext{
${ }^{43}$ H.S. Singh; J. Mullen, S. Udas, Court sentences 4 men to death in New Delhi gang rape case, September 14, 2013, http://edition.cnn.com/2013/09/13/world/asia/india-gang-rape-sentence/; inny przykład: Światowa Koalicja Przeciw Karze Śmierci (World Coalition Against The Death Penalty), Iran executes for juvenile offenders in one week, 28 April 2014. http://www.worldcoalition.org/iran-executions-juvenileoffenders-children-rights.html.

44 Jest to część szerszego problemu zmienności standardów moralnych (evolving standard of decency), zob. np. R.P. Alford, Misusing International Sources to Interpret the Constitution, Notre Dame Law School, Scholarly Works 2004, s. 60-61, http://scholarship.nd.edu/law_faculty_scholarship/565. Z kolei sędzia A. Scalia przeciwstawia obcym wzorom amerykańskie standardy moralne jako wiążące, zob. B. Markesinis, J. Fedtke, The Judge as Comparatist, Tulane Law Review, No. 80/2005-2006, s. 21.

${ }^{45}$ Skrajny pogląd, że obce standardy są wiążące $w$ interpretacji konstytucji reprezentuje J. Fitzpatrick, zob. Z. Larsen, op. cit., s. 1297.
} 


\section{回 \\ WNIOSKI}

Kosmopolityzm prawny przejawia się w powstawaniu reguł postępowania oderwanych od woli suwerennych państw. Zjawisko to obejmuje również sędziów, którzy zapożyczają obce konstrukcje prawne lub sięgają wprost do przepisów i wyroków z innych systemów prawnych. W przypadku sędziów odrywanie się od źródeł krajowych wiąże się z wykorzystaniem istniejących kompetencji i struktur organizacyjnych. Odróżnia to kosmopolityzm sędziowski od systemów takich jak lex sportiva, które tworzą swoje własne zasady organizacyjne i ramy ustrojowe, w tym sądownictwa sportowego. Kosmopolityzm sędziowski jest zatem w pewnym sensie przemycany w granicach istniejących ram prawnych, przy okazji interpretowania prawa krajowego. Ta cecha czyni go szczególnie trudnym do odróżnienia od zwykłej interpretacji prawa. Nie są też łatwo uchwytne granice pomiędzy inspiracją intelektualną a traktowaniem obcego prawa jako podstawy orzekania, co w rzeczywistości prawie nigdy nie występuje, z wyjątkiem krajów anglosaskich powiązanych ze sobą wspólnym dziedzictwem kultury prawnej oraz byłych krajów kolonialnych i ich metropolii ${ }^{46}$.

Sięganie po obce wzory i doświadczenia nie oznacza z definicji naruszania własnego prawa i ma poważne zalety, z których najważniejszą jest możliwość wstępnej oceny skutków społecznych i ekonomicznych decyzji, jeśli podobna decyzja lub rozwiązanie prawne zostały już wcześniej podjęte w innym kraju. Jednak traktowanie obcych przepisów i precedensów jako wiążących lub stosowalnych bezpośrednio jest w większości systemów prawnych niedopuszczalne bez umocowania w wyraźnym przepisie konstytucji. Dotyczy to także prawa europejskiego, które w świetle orzecznictwa nie dopuszcza prawa obcego jako formalnej podstawy orzekania, a nawet - przeciwnie - selektywnie podporządkowuje je sobie, o czym świadczy sposób rozwiązywania konfliktów między prawem sportowym a wolnościami wspólnego rynku ${ }^{47}$.

\footnotetext{
${ }^{46} \mathrm{~S}$. Choudhry, Globalisation in Search of Justification. Toward a Theory of Comparative Constitutional Interpretation, Indiana Law Journal, No. 74/1999, s. 833.

47 Potwierdzenie nadrzędności prawa wspólnotowego znalazło wyraz w takich sprawach jak ETS Bosman C-415/93, ECR. 1995, s. 0492; Deliège C-51/96, ECR. 2000, s. 02549; Kolpak C-438/00, ECR. 2003, s. 4135; Simutenkow C-265/03, ECR 2003, I-2579; Meca-Medina (Oulmers) C-519/04P, ECR 2006, s. 6991.
} 
Kosmopolityzacja orzecznictwa, nawet w łagodniej wersji polegającej na inspiracji intelektualnej, rodzi poważne niebezpieczeństwa. Wynikają one przede wszystkim z niedoskonałości metodologicznej oraz narastającego udziału koncepcji filozoficznych w interpretacji prawa. Przedstawione w piśmiennictwie praktyki wskazują na brak zastosowania jakiejkolwiek metody. Jak pisze R.J. Krotoszyński, ,„Jak można sensownie 'pożyczać' precedensy, jeśli się nie rozumie nawet na poziomie podstawowym instytucji, która wydała decyzję, ani prawnych, społecznych i kulturowych ograniczeń tworzących jej tło?"48.

Przypadkowość „odkryć” powoduje, że inspiracją niekoniecznie stają najlepsze światowe wzorce, lecz te, które przypadkiem są dostępne sędziom. Zapożyczenia aksjologiczne mogą stanowić problem wtedy, gdy dokonywane są z systemów uznających odmienne wartości podstawowe niż w państwie wyrokowania. Choć wykorzystywanie obcych doświadczeń do oceny skutków decyzji wydaje się korzystne dla społeczeństwa, to jednak sędziowie powinni powstrzymywać się od wykorzystywania obcych źródeł prawa do nadawania treści przepisom konstytucyjnym.

Oceniając kosmopolityczną emancypację sędziów trzeba też zwrócić uwagę na jej sprzeczność z zasadami państwa prawnego i demokracji. Szczególnie niebezpieczne jest upodabnianie się działalności orzeczniczej do prawotwórczej. Mimo że w piśmiennictwie występuje silna tendencja do uzasadniania i ukrywania tego zjawiska przez nadawanie nowych znaczeń utrwalonym pojęciom takim jak „praworządnośćc lub „demokracja" ${ }^{\prime 49}$, to jednak warto przypomnieć, że sądy zostały stworzone do ochrony zastanych instytucji prawnych, a nie poszukiwania nowych.

\footnotetext{
48 R.J. Krotoszyński,,,I'd Like to Teach the World Sing (In Perfect Harmony)": International Judicial Dialogue and the Muses - Reflections on the Perils and the Promise of International Judicial Dialogue, Michigan Law Review, No. 104/2006, s. 1325.

${ }^{49} \mathrm{~Np}$. pogląd, że dotychczasowe pojęcie demokracji większościowej należy zastąpić pojęciem demokracji zagregowanej, tak A-M. Slaughter, Global Government Networks, Global Information Agencies, and Disagregated Democracy, Michigan Journal of International Law, No. 24/2002-2003, s. 1066-1073.
} 